\title{
DISCIPLINARY CONSTRUCTION AND CULTIVATION SYSTEM OF WUSHU AND NATIONAL TRADITIONAL SPORTS
}

\author{
SISTEMA DE CONSTRUÇÃO E CULTIVO DISCIPLINARDE WUSHU EESPORTES TRADICIONAIS \\ NACIONAIS
}

SISTEMA DE CONSTRUCCIÓN Y CULTIVO DISCIPLINARIO DEL WUSHU Y DEPORTES TRADICIONALES NACIONALES

\author{
Yihong Fan' (D) \\ (Physical Education Professional) \\ 1. Institute of physical and health \\ education, Guangxi Normal \\ University, Guilin, China.
}

\section{Correspondence:}

Guilin. 541000, China.

540994665@qq.com

\begin{abstract}
Introduction: With the advent of the network information age, the teaching of martial arts and traditional national sports has broken the limitations of the previous "teaching by precept and deeds" and combined with computer information technology to construct a teaching resource system for martial arts and traditional national sports, realizing the sharing of teaching resources. Objective: The article determines the concept of teaching resource integration by formulating a resource integration plan for the teaching resource system of martial arts and traditional national sports majors. At the same time provides a theoretical basis for the resource integration of the teaching resource system. Methods: The article takes the general university martial arts and national traditional sports discipline model as the research object, uses the method of literature data, investigation, logical analysis and other methods to research some general university martial arts and traditional national sports discipline curriculum models, and analyzes the existing ones. Results: The article formulated the resource integration plan of the professional teaching platform and provided theoretical guidance for the resource integration of the professional teaching resource platform. Secondly, it analyzes the advantages and disadvantages of resource integration of the teaching resource platform combining martial arts and sports. It proposes corresponding improvement suggestions to improve the quality and efficiency of the teaching resource platform. Conclusions: The teaching resource platform combining martial arts and physical education forms a relatively complete teaching resource system; reasonable teaching resource module design; realizes the network sharing of professional teaching resources in colleges and universities; the martial arts rank system highlights the key points and demonstrates the characteristics of the times. Level of evidence Il; Therapeutic studies - investigation of treatment results.
\end{abstract}

Keywords: Martial arts; Physical education and training; Students.

\section{RESUMO}

Introdução: Como advento da era das redes de informação, o ensino das artes marciais e dos esportes nacionais tradicionais rompeu as limitações do antigo "ensino por preceito e fatos" efoi combinado com a tecnologia da computação para construir um sistema de recursos didáticos para as artes marciais. artes e esportes tradicionais nacionais, fazendo a troca de recursos didáticos. Objetivo: o artigo determina o conceito de integração de recursos didáticos formulando um plano de integração de recursos para o sistema de recursos didáticos das carreiras das artes marciais e dos esportes tradicionais nacionais. Ao mesmo tempo, fornece uma base teórica para a integração de recursos do sistema de recursos de ensino. Métodos: 0 artigo toma 0 modelo geral das artes marciais universitárias e o modelo da disciplina nacional de esportes tradicionais como objeto de pesquisa, usa o método de dados da literatura, pesquisa, análise lógica e outros métodos para investigar alguns modelos de currículo geral de artes marciais universitárias e disciplinas desportivas nacionais tradicionais. e analisar os existentes. Resultados: o artigo formulou o plano de integração de recursos da plataforma de ensino profissional e forneceu orientações teóricas para a integração de recursos da plataforma de recursos de ensino profissional. Em segundo lugar, ele discute as vantagens e desvantagens de integrar recursos da plataforma de recursos de ensino que combina artes marciais eesportes. Propõe as correspondentes sugestões de melhoria para melhorar a qualidade e eficiência da plataforma de recursos didáticos. Conclusōes: A plataforma de recursos didáticos que combina artes marciais e educação física forma um sistema de recursos didáticos relativamente completo; projeto de módulo de recursos de ensino razoável; Inclui o intercâmbio de redes de recursos de ensino profissional em faculdades e universidades; o sistema de classificação das artes marciais destaca os pontos-chavee demonstra as características da época. Nível de evidência ll; Estudos terapêuticos: investigação dos resultados do tratamento.

Descritores: Artes marciais; Educação física e treinamento; Estudantes.

\section{RESUMEN}

Introducción: Con el advenimiento de la era de la información en red, la enseñanza de artes marciales y deportes nacionales tradicionales ha roto las limitaciones de la anterior "enseñanza por precepto y hechos" y se ha combinado con la tecnología informática para construir un sistema de recursos didácticos para artes marciales y deportes nacionales tradicionales, realizando el intercambio de recursos didácticos. Objetivo: El artículo determina el concepto de integración de recursos didácticos mediante la formulación de un plan de integración de recursos para el sistema de recursos didácticos de las carreras de artes marciales y 
deportes nacionales tradicionales. Al mismo tiempo, proporciona una base teórica para la integración de recursos del sistema de recursos didácticos. Métodos: El artículo toma el modelo general de artes marciales universitarias yel modelo de disciplina deportiva tradicional nacional como objeto de investigación, utiliza el método de datos de literatura, investigación, análisis lógico y otros métodos para investigar algunos modelos de currículo de artes marciales universitarias generales y disciplinas deportivas nacionales tradicionales. y analiza los existentes. Resultados: El artículo formuló el plan de integración de recursos de la plataforma docente profesional y brindó orientación teórica para la integración de recursos de la plataforma de recursos docentes profesionales. En segundo lugar, analiza las ventajas y desventajas de la integración de recursos de la plataforma de recursos didácticos que combina artes marciales y deportes. Propone las correspondientes sugerencias de mejora para mejorar la calidad y la eficiencia de la plataforma de recursos didácticos. Conclusiones: La plataforma de recursos didácticos que combina artes marciales y educación fisica forma un sistema de recursos didácticos relativamente completo; diseño de módulo de recursos didácticos razonables; comprende el intercambio de redes de recursos docentes profesionales en colegios y universidades; el sistema de clasificación de las artes marciales destaca los puntos clave y demuestra las características de la época. Nivel de evidencia ll; Estudios terapéuticos: investigación de los resultados del tratamiento.

Descriptores: Artes marciales; Educación y entrenamiento físico; Estudiantes.

\section{INTRODUCTION}

Inheriting and carrying forward the teaching resources of martial arts and traditional national sports is an essential means to inherit the Chinese nation's traditional culture, promote national fitness exercise, and promote modern people's physical and mental health. ${ }^{1-2}$

The article determines the concept of teaching resource integration by formulating a resource integration plan for the professional teaching resource platform of martial arts and traditional national sports, and at the same time provides a theoretical basis for the resource integration of the teaching resource platform. The article analyzes the advantages and disadvantages of resource integration in the teaching resource platform. It proposes corresponding improvement measures to improve the quality and efficiency of the teaching resource platform. Put forward the concept of developing the teaching resource platform of Wushu and traditional national sports, and provide a feasible reference for the sustainable development of the teaching resource platform.

\section{METHOD}

\section{Research object}

This article takes the discipline construction model of traditional national sports in ordinary colleges and universities as the research object.

\section{Research methods}

\section{Literature data method}

The article uses electronic and manual retrieval methods to consult related papers, monographs and other theoretical results.

\section{Investigation method}

Some experts and teachers in colleges and universities were interviewed by telephone in response to corresponding issues. The thesis investigates the corresponding issues such as the curriculum setting, credits, and class hour ratio in colleges and universities in the form of a questionnaire.

\section{Evaluation of teaching quality of combining martial arts and physical education based on BP neural network}

The quality evaluation model of combining martial arts and physical education based on the BP neural network is shown in Figure 1. BP neural network needs continuous learning to optimize the network structure parameters, namely the connection weight $\omega_{i j}$ between the input layer and the middle layer, the connection weight $B$ between the middle layer and the output layer, and the middle layer neuron node threshold $\theta_{i}$ and the output layer Neuron node threshold $\theta_{k}$, to finally realize that the deviation between the actual output A and the ideal output $G_{k i}$ of the BP neural

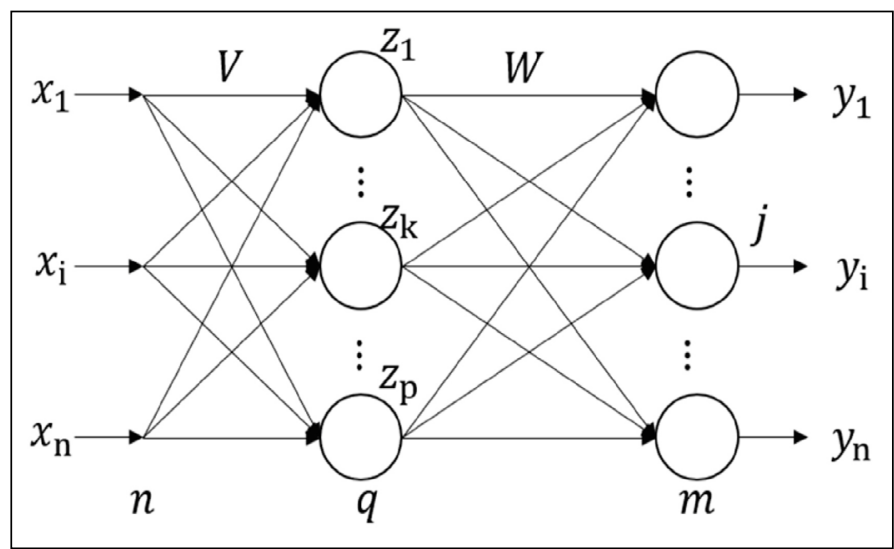

Figure 1. The quality evaluation model of combining martial arts and physical education based on BP neural network.

network is reduced to the specified error accuracy range. ${ }^{2}$ Because the selection of structural parameters such as the initial connection weights and thresholds of the BP neural network has a significant impact on the network output results, because of the slow convergence of the traditional BP algorithm, the initial values of parameters such as $\omega_{i j}, G_{k i}, \theta_{i}, \theta_{k}$ are more sensitive. The conditions such as local extremes are easy to fall into, a new method is proposed. The improved particle swarm algorithm optimizes the output of the optimal initial connection weights and thresholds, such as $\omega_{i j}, G_{k i}, \theta_{i}, \theta_{k}$ in the BP neural network, and the BP neural network is learned and trained by the improved BP algorithm until the output error of the BP neural network meets the requirements.

To avoid the standard BP algorithm falling into a local minimum and possible oscillations during the learning and training process, the paper adopts the improved BP algorithm based on momentum and adaptive learning as shown in equations (1) and (2). By adding momentum term, oscillation can be avoided in network learning training; by introducing adaptive learning factors to adjust the learning rate, it can avoid system oscillation and even divergence caused by too large or too small learning rate slow convergence speed.

$$
\omega_{i j}(t+1)=\omega_{i j}(t)+\eta(t+1) \sigma(t) X_{i}(t)+\beta\left|\omega_{i j}(t)-\omega_{i j}(t-1)\right|
$$

$$
\eta(t+1)=\left\{\begin{array}{l}
c \eta(t)\left[\sigma(t) X_{i}(t)\right],\left[\sigma(t-1) X_{i}(t-1)\right]>0 \\
d \eta(t)\left[\eta(t) X_{i}(t)\right],\left[\eta(t-1) X_{i}(t-1)\right]<0 \\
\eta(t)\left[\sigma(t) X_{i}(t)\right],\left[\sigma(t-1) X_{i}(t-1)\right]=0
\end{array}\right.
$$


Among them, $\beta$ is the momentum factor, $\omega_{i j}(t)-\omega_{i j}(t-1) \mid$ is the added momentum term; $\mathrm{c}, \mathrm{d}$ are constants, and $0<c<d ; \eta$ is the learning rate (learning step size) that needs to be adjusted; $\sigma$ is the error between the network neuron layers; $X_{i}$ is the BP neural network Layer input signal. The standard particle swarm (PSO) algorithm performs iterative calculations according to equations (3) and (4) until the particles search for the optimal position.

$V_{i j}(t+1)=\omega V_{i j}(t+1)+\gamma_{1} \times \operatorname{rand}_{1} \times\left(P_{j}(t)-S_{i j}(t)\right)+\gamma_{2} \times \operatorname{rand}_{2} \times\left(G_{j}(t)-S_{i j}(t)\right)(3)$

$$
S_{i j}(t+1)=S_{i j}(t)+V_{i j}(t+1)
$$

Among them, tis the number of optimization iterations; $S_{i j}(t)$ is the current position of the particle at generation $\mathrm{t} ; V_{i j}(t)$ is the velocity of the particle at generation $t ; \omega$ is the inertia weight of particle motion, and $\gamma_{1}, \gamma_{2}$ is the acceleration factor. The maximum step length of the movement of the individual optimal particle position direction, select $\gamma_{1}=\gamma_{2}=2 ;$ rand $_{1}$, rand $_{2}$ are the random number from 0 to 1 .

$$
\omega=\omega_{\max }-\frac{t \times\left(\omega_{\max }-\omega_{\min }\right)}{t_{\max }}
$$

$\omega_{\max }$ is the maximum value of inertia weight, $\omega_{\min }$ is the minimum value of inertia weight, $t$ is the current update iteration number, and $t_{\max }$ is the maximum update iteration number. ${ }^{3}$ To expand the particle swarm algorithm's search and optimization space, reduce or even eliminate the probability that the particle swarm will fall into the local extreme value before the complete search. When the particle is updated each iteration, the particle is reinitialized according to a particular mutation probability g. In referring to the idea of population variation in genetic algorithm, we introduce genetic variation factor to realize the global optimization of particle swarm algorithm. The operation method is:

$$
X_{i j}=\left\{\begin{array}{l}
X_{i j}+\left(X_{i j}-X_{\max }\right) \times h \times\left(1-\frac{t}{t_{\max }}\right) h \geq 0.5 \\
X_{i j}+\left(X_{\max }-X_{i j}\right) \times h \times\left(1-\frac{t}{t_{\max }}\right) h<0.5
\end{array}\right.
$$

Among them, $\mathrm{h}$ is a random value between 0 and 1 , which determines the particle's variation toward the maximum or minimum position. Obtain the mutation probability $g$ from equation (7):

$$
g^{t}=\frac{\left(g_{1}+g_{2}\right)+\left(g_{1}-g_{2}\right) \times \cos \left(\pi t / t_{\text {max }}\right)}{2}
$$

Among them $g_{1}, g_{2}$ is the initial value and final value of the mutation probability, respectively, and $g_{1}, g_{2}$ is selected to ensure that the mutation probability g gradually increases according to the law of cosine change. Improved particle swarm algorithm and BP algorithm optimization training BP neural network process is shown in Figure 2.

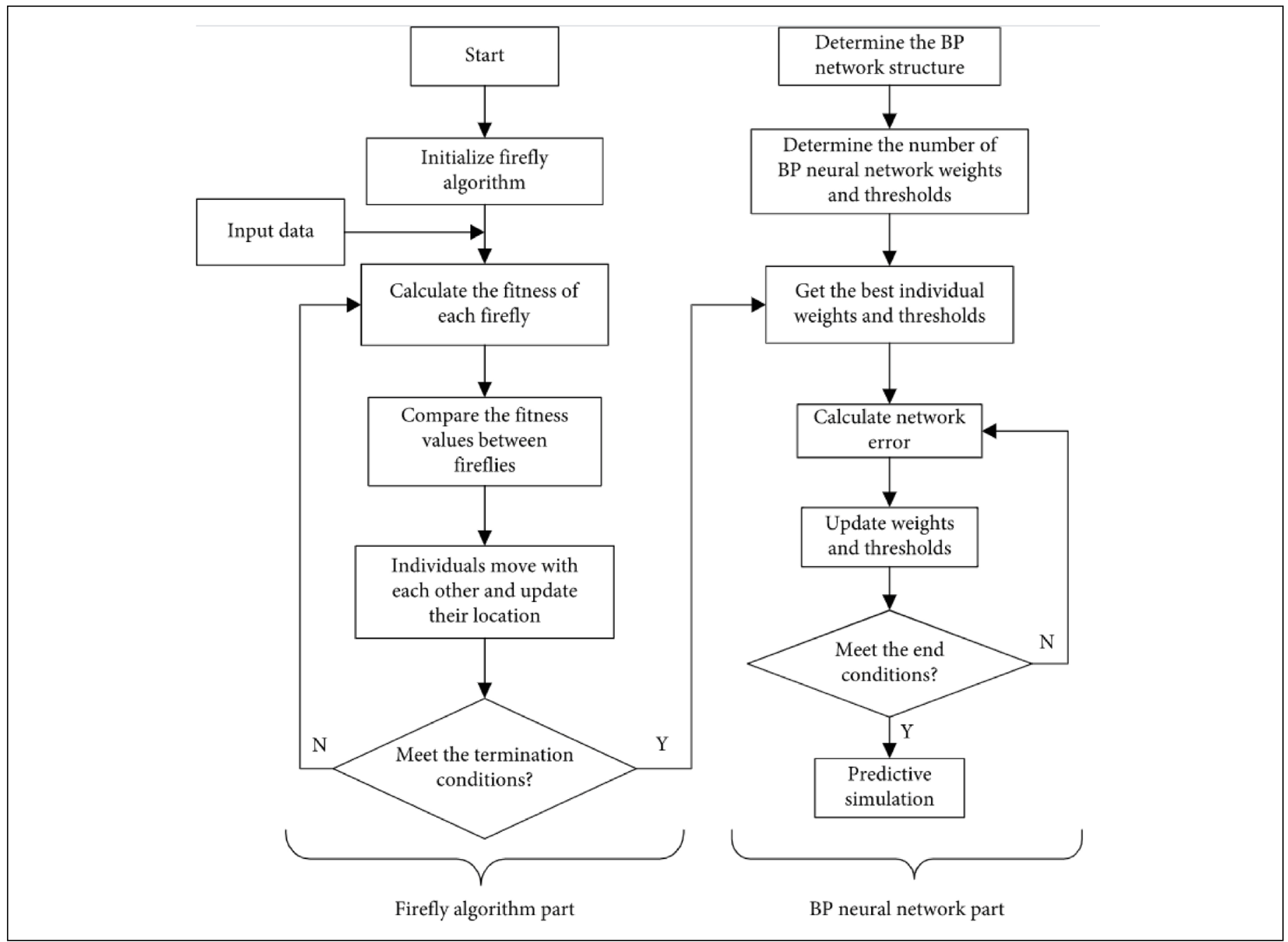

Figure 2. BP neural network optimization training process. 


\section{RESULTS}

\section{Curriculum setting and credit distribution of national tradi- tional sports disciplines in different universities}

Curriculum setting and class hours allocation for the undergraduate major of ethnic traditional sports in C University

C university's national traditional sports major began to enroll students in 1996, and the primary school system is four years. Complete 176 credits according to the teaching plan. Compulsory courses are 109.5 credits, accounting for $62.2 \%$, and elective courses are 33 credits, accounting for $18.6 \%$ (Table 1).

\section{University National Traditional Sports Undergraduate Ma- jor Curriculum Setting and Class Hours Allocation}

The national traditional sports major of $D$ University began to recruit students in 2001 with a bachelor's degree. The academic system of professional courses is four years, and the length of study is 3-6 years. Through all the teaching links specified in the training program, the total credits reach 170 credits. Graduation thesis grades reach a pass or above.

\section{Problems in the construction of traditional ethnic sports disciplines in colleges and universities}

Table 1. Types of courses and hours allocation for ethnic traditional undergraduate majors in University $C$.

\begin{tabular}{c|c|c|c}
\hline & & Credit & Proportion \\
\hline \multirow{2}{*}{$\begin{array}{c}109.5 \text { credits of compulsory } \\
\text { courses, accounting for 62.2\% }\end{array}$} & Public basic course & 39.5 & $22.40 \%$ \\
\cline { 2 - 4 } & Professional Basic Course & 24 & $13.60 \%$ \\
\cline { 2 - 4 } & Professional Course & 46 & $30 \%$ \\
\hline \multirow{2}{*}{$\begin{array}{c}33 \text { credits of elective courses, } \\
\text { accounting for 18.6\% }\end{array}$} & Limited elective courses & 23 & $13.00 \%$ \\
\cline { 2 - 4 } & Any optional courses & 10 & $6 \%$ \\
\hline \multicolumn{2}{c}{ practical teaching } & 33.5 & $19 \%$ \\
\hline \multicolumn{2}{c}{ total } & 176 & $100 \%$ \\
\hline
\end{tabular}

Table 2. Technical courses offered for undergraduate majors in traditional ethnic sports.

\begin{tabular}{c|c|c|c|c}
\hline & A & B & C & D \\
\hline Dance dragon & & $\sqrt{ }$ & & \multirow{2}{*}{} \\
\hline Lion dance & $\sqrt{ }$ & $\sqrt{ }$ & $\sqrt{ }$ & \\
\hline Routine & $\sqrt{ }$ & $\sqrt{ }$ & & $\sqrt{ }$ \\
\hline Sanda & $\sqrt{ }$ & $\sqrt{ }$ & $\sqrt{ }$ & $\sqrt{ }$ \\
\hline Taekwondo & $\sqrt{ }$ & $\sqrt{ }$ & $\sqrt{ }$ & $\sqrt{ }$ \\
\hline Chinese wrestling & & $\sqrt{ }$ & $\sqrt{ }$ & \\
\hline Other & & $\sqrt{ }$ & & \\
\hline
\end{tabular}

Note: $\sqrt{ }$ : means this course is offered.

\section{There are differences in theoretical courses}

The national traditional sports professional curriculum system is distinguished from courses, which can be divided into technical courses, theoretical courses, and practical courses. National traditional sports professional courses are divided according to learning orientation, which can be divided into four levels: public required courses, professional required courses, restricted elective courses and arbitrary courses. ${ }^{4}$ There are specific differences in theoretical courses in schools with undergraduate majors in traditional ethnic sports or graduate students in traditional ethnic sports. Major compulsory courses are mostly: exercise physiology, sports biochemistry, sports training, sports anatomy, sports psychology, sports statistics; most of the compulsory courses are: Chinese martial arts history, traditional health preservation and traditional Chinese medicine theory; any courses are mostly: Sports biomechanics, sports research and sports biochemistry, etc. According to expert interviews and investigations, there are differences in the scale of enrollment, infrastructure, and various colleges' faculty. It can be seen that these colleges and universities are determined based on the physical equipment and the strength of their teachers. They do not strictly follow the scientific point of view and violate the law of traditional sports development.

\section{A significant disparity in the allocation of class hours}

There are big differences in the allocation of ethnic traditional majors in various universities. According to the statistical results, the four colleges'allocation of ethnic traditional majors is concentrated in 1312-2116 hours. The gap is quite large, with a difference of 804 hours. Of course, this difference allows schools to teach following their conditions and implement specific teaching according to teachers, facilities, equipment, etc., which is more flexible. However, it is not conducive to the potential development of teachers, facilities, and equipment. It is more likely that teachers will feel that the existing technology has already met work and teaching needs. It does not hinder their enthusiasm for learning and enterprising, which is not conducive to developing the subject.

\section{ANALYSIS OF THE EXISTING PROBLEMS IN THE CONSTRUCTION OF THE DISCIPLINE OF TRADITIONAL NATIONAL SPORTS}

\section{The problem of imperfect technology and development model construction}

The "learning" of traditional national sports not only includes the construction of the technical system of traditional national sports but also includes the intervention and influence of traditional national sports culture and other disciplines on the research of traditional national sports, and pays more attention to the construction of traditional national sports theory. The "technique" of traditional national sports focuses on technical characteristics and technical styles. However, when people look at the two, they often use "learning" instead of "shu" and equate "shu" with "learning."This conceptually logical error restricts traditional national sports and their culture and invisibly promotes the unsound transplantation of traditional national sports and Chinese traditional culture. ${ }^{5}$ This will narrow the space for traditional national sports development, and even unhealthy grafting and transplantation will occur.

\section{The problem of imperfect professional research institution system}

Even few colleges and universities are enrolling traditional national sports majors. For some time, researchers have paid too much attention to the partial research of some specific issues and the research that can bring certain benefits while ignoring the fundamental theoretical research that can withstand the test of time. ${ }^{6}$ Therefore, we need to comprehensively plan and guide the disciplines of traditional national sports to continuously improve the professional research institution system of traditional national sports, and form a way to continuously track the frontiers of the discipline, track the development of international sports culture, and constantly update the research field.

\section{DISCUSSION}

1. We need to establish a standardized theoretical curriculum framework for traditional ethnic sports and a diverse technical framework for traditional ethnic sports. 2. We need to focus on the cultivation of professional teachers of traditional national sports and disseminating and researching the cultural nature of traditional national sports. 3. Strengthen communication and research cooperation between regions and universities, develop advantageous projects in various regions, and establish a way of radiation to the surroundings with substantial projects as the center, providing a bridge for traditional sports' networked communication. 


\section{CONCLUSION}

Study Design: the study takes the general university martial arts and national traditional sports discipline model as the research object, uses the method of literature data, investigation, logical analysis and other methods to research some general university martial arts and traditional national sports discipline curriculum models, and analyzes the existing ones.

Clinical Relevance Statment: the study shows in teaching and subject construction, it emphasizes the value of technical courses, neglects the whole school's development plan.
According to their schools' specific conditions, their respective schools set the courses set by colleges and universities with national traditional sports majors or master's degrees. There is a phenomenon that the curriculum is not standardized. In teaching and subject construction, it emphasizes the value of technical courses, neglects the whole school's development plan. The research on the resource integration of the professional teaching resource platform of martial arts and traditional national sports has essential theoretical and practical significance.

The author declare no potential conflict of interest related to this article

AUTHORS' CONTRIBUTIONS: The author made significant contributions to this manuscript. Yihong Fan: writing and performing surgeries; data analysis and performing surgeries; article review and intellectual concept of the article.

\section{REFERENCES}

1. Podrigalo L, lermakov S, Romanenko V, Rovnaya O, Tropin Y, Goloha V, et al. Psychophysiological features of athletes practicing different styles of martial arts-the comparative analysis. Int J Appl Exerc Physiol. 2019;8(1):84-91.

2. Santos-Junior RB, Utter AC, McAnulty SR, Bernardi BR, Buzzachera CF, Franchini E, et al. Weight loss behaviors in Brazilian mixed martial arts athletes. Sport Sciences for Health. 2020;16(1): 117-22.

3. Parry J, Wagner M. The contribution of martial arts to moral development. Ido Movement for Culture. J Martial Arts Anthrop. 2019;19(1):1-8.

4. Eganov A, Cherepov E, Bykov V, Tselishcheva E. Coordination abilities responsible for technical actions in martial arts at various levels of motor dichotomy of upper limbs. Journal of Physical Education and Sport. 2020;20(2):848-51.

5. Kirk C, Clark DR, Langan-Evans C, Morton JP. The physical demands of mixed martial arts: A narrative review using the ARMSS model to provide a hierarchy of evidence. J Sports Sci. 2020;38(24):2819-41.

6. Coswig VS, Miarka B, Pires DA, Da Silva LM, Bartel C, Del Vecchio FB. Weight regain, but not weight loss, is related to competitive success in real-life mixed martial arts competition. Int J Sport Nutr Exerc Metab. 2019;29(1): 1-8. 